OPEN ACCESS

ISSN 2541-2841 (online) ISSN 2302-6790 (print)

Edited by:

Poppy Febriana

${ }^{*}$ Correspondence:

Carragh Y. Ferguson

fergusoncarragh@gmai

l.com

Citation:

Carragh Y. F., Pramita H., Ratnasari I. (2021) Relationship

Marketing Activities in Building

Customer-Oriented Marketing

Services, Kanal, 9(2).

Doi:10.21070/kanal.v9i2.1014

\section{Relationship Marketing Activities in Building Customer-Oriented Marketing Services}

\author{
Carragh Yutiana Ferguson ${ }^{1 *}$, Hendi Paramita ${ }^{2}$, Indira Ratnasari ${ }^{3}$ \\ 1,2,3Communication and Business LSPR Jakarta, Indonesia
}

\begin{abstract}
The aim of this study is to know how does relationship marketing activities in building customer-oriented marketing services. For this research, relationship marketing is used as it's main theory, and the tool to conduct this research is through descriptivequalitative methodology, with two informants from Singapore Intercultural School Bona Vista, first informant Head of Marketing of SIS Group of Schools and second informant Parents Relation Officer and Marketing Manager of Singapore Intercultural School Bona Vista as primary data. The research findings indicate that SIS Bona Vista has done well with their relationship marketing activities in building customer-oriented marketing services through pre sales mainly Digital: Website, Instagram, Facebook, Twitter, Google Ads, SEO, SEM where then they continue to email greeting such sharing information about the school, sending useful articles and in Traditional, reaching out to communities such Embassies of Korea and Japan. During sales when the target market visited Indonesia, they will book a school tour - "moment of truth" and an after sale an Alumni Group. Internal communication with existing parents it's an open and flexible communication, through WhatsApp, email, Social Media. Parents and teacher through WhatsApp group. A weekly overall information through "SIS Connect" and internal application named "Academia".
\end{abstract}

Keywords: Relationship Marketing, Integration Marketing Communication, Customer Oriented. 


\section{INTRODUCTION}

Education is playing an important part in all of the world, it's the main primary need of a human being not only that children learn from being in school, they are also socialising to others that created the connection between each other. From school they learn the ideology of the foremost fountain of knowledge children are exposed to. It gives a chance for them to acquire knowledge on various fields of education such as people, literature, history, mathematics, politics, and other numerous subjects. This contributes to cultivation in the thought process. The thought process on solving problems that correlate to the need of the leadership in every countries, because at the end of the day human being will have to return back to the community.

Indonesia is sitting as the four largest education systems in the world, supported by minister of education, "do not forget that Indonesia has among the four largest education systems in the world. The role of technology is imperative, "Education and Culture Minister Nadiem Anwar Makarim (Cindyara, 2019). Three hundred thousand schools within the loop of private nor public schools and fifty million students in Indonesia, the outgrowth of competition is steadily revolutionized.As competition is steadily outgrowth in education sector, the organizations seek to build a strong brand for the product.

Singapore Intercultural School Bona Vista referred to SIS BV is an independent co-educational institution offering university preparation programmed for both local and expatriate students, that is located in Lebak Bulus, South Jakarta. As Singapore Intercultural School Bona Vista is a part of SIS Group of Schools, whereby, SIS has seven schools across Indonesia The competitor of SIS Bona Vista is Jakarta Intercultural School along with British Jakarta School, then Sekolah Pelita Harapan, ACS and Global Jaya. However, with thecompetition that is known, the uniqueness of Singapore Intercultural School Bona Vista as they followed Singapore Curriculum, Cambridge Assessment International School and International Baccalaureate and they have two COHORT, SIS Bona Vista 1 which Academic Year starts from January to December which is mainly expatriateand Bona Vista 2 which Academic Year starts from July to June. Another uniqueness' SIS BV believe curiosity is the engine of achievement.

Thus this statement is being supported by the survey that Singapore Intercultural School Bona Vista has gathered in April 2018 with 74 respondents to the QuestionnairesLikert scale with the percentage of total from Elementary classes $15,07 \%$, total of Primary classes $54,80 \%$ and total of Secondary classes $12,33 \%$. Highlight of the 13 questions, these statements supported the statement that SIS Bona Vista value and implement premium services of education which correlate to the customer-oriented marketing services they have built with their customers, question 2 with high percentage of $59,46 \%$ has agreed that their child is happy in Singapore Intercultural School Bona Vista, and question 10 with high percentage of $66,67 \%$ has agreed that the school engages with parents on regular basis.

That being stated maintain relationship with customer is precious in anyway, the interactive process of learning and customization - who they are, what do they want, how much they buy and how much cost to serve these customers. Gumersson (2011) defined relationship marketing as "interaction in network relationships". The result of relationship marketing is marketing network. It is a profitable - mutual relationship of stakeholders, consists of customers, employees, suppliers and others related to the company (Kotler \& Keller, 2014). That narrowed down to relationship marketing would work well when the business services successfully manage the customer relationship.

Customers are assets that play an important role in determining the success of the company the efforts to create and retain customers.Loyal customers serve as an unbiased source of information, no strings attached, which is even more convincing than company's marketing efforts. Brand advocates will bring business, at no cost, simply through their recommendations. "The proof is in the profit: existing customers spend an average of $67 \%$ more than first time customers. In fact, repeat customers make up only $8 \%$ of all customers but account for $40 \%$ of a company's revenue. Loyal customers spend more money per visit than new customers, bringing us to number five." (Garfinkel, 2019). Therefore, it's needed for Marketing department to have loyal customers that eventually will become their brand community, an influential people that do word of mouth to other potential target. Kotler and Keller (2016) "Brand community is a specialized community of consumers and employees whose identification and activities focus around the brand".

The research objective of this paper is to know how relationship marketing activities to build customer-oriented marketing services in Singapore Intercultural School Bona Vista, Jakarta.

Main theory in this research is Relationship Marketing as an integrated activity of marketing strategy. While for some people, the basic marketing practice would be selling products to customers. Through the development of practices, marketers build relationships with customers to have longterm customer loyalty (Gumersson, 2011). We should take a look at the big picture of relationship marketing. Since implementing marketing strategy would be hard if marketing management stand-alone without support from other departments. Quality and customer service both support the marketing objective. Relationship marketing stands as an integrated strategy to maximize the customer-oriented marketing services (Christopher, Payne \& Ballantyne, 1991).

Renart and Cabre (2005) justify through 'Keys to Effective Relationship Marketing' the next aspect of relationship marketing which is three steps of designing customer relationship strategy. First step is defining the corporate mission, values and culture. Second design is the 
relationship strategy, (a) how would the strategy relate to the customers? (b) how to identify customer needs? (c) what are the relationship activities? (d) what are the terms and conditions requirements for customer to participate?

Third step is acquiring means and resources. Company should manage the channel of relationship application such websites, business intelligence and customer database to develop successful relationship. The most common are call center, emails, customer care, after sales services (Renart \& Cabre, 2005).

Seven keys to effective relationship marketing explain the planning steps to implement a feasible and sustainable relationship (Renart \& Cabre, 2005). Supporting theories are Customer-oriented marketing services, Fill and Turnbill (2016), Customer-oriented marketing services has been mentioned as Integrated Marketing Communication, whereas, customer-oriented is a part of Integration Marketing Communication where the application of IMC is:

1. Use of multiple media in planning and delivering marketing communications messages.

2. Primacy of consumer understanding as the kernel of marketing communication planning and execution.

3. Use of proprietary frameworks or processes for IMC planning, including measurement tools by both clients and agencies.

Whereby Integration of Marketing Communication's definition by Fill and Turnbill "IMC can represent both a strategic and tactical approach to the planned management of an organization's communications. IMC requires that organization coordinate their various strategies, resources and messages in order that they enable meaningful engagement with audiences. The main purposes are developing a clear positioning and encourage stakeholder relationships that are mutual value" (Fill and Turnbill, 2016).

Persuasion Knowledge Model by Friested and Wright, 1994 is marketing-focused. The focus has been on the interaction between marketers and consumers, persuasion tactics affects consumers' responses to such tactics (Friested \& Wright, 1994). Model asserts that over time, consumers develop knowledge of marketer's persuasion tactics and being better to adapt and respond to such attempts to achieve individual goals. The decomposition of persuasion process into two elements: the target and agent, which, the target refers to intended recipient of the persuasion attempt (the consumer), whereas, the agent represents whom the target identify as the creator of the persuasion (the marketer). The persuasion attempt encompasses not only the message of the agent, which is influenced by the marketer's knowledge of the topic, target and the effectiveness and applicability of different persuasion tactics but also the target market's perception of marketer's persuasion strategy.

In summary, key contribution of Friested and Wright persuasion knowledge model is that the consumers are active and knowledgeable participants in marketers' persuasion efforts and the persuasion knowledge includes motivation, cognitive ability and goals are all factors that will be consider into examining the effectiveness of marketing attempt of persuasion. The model is useful for the marketer and target market, it provides the marketers an understanding of how consumers react to persuasion attempts and guide on how to minimize persuasion knowledge activation.

\section{RESEARCH METHOD}

This study is using descriptive-qualitative method in order to analyses the communication process of how Singapore Intercultural School Bona Vista relationship marketing activities build their customer-oriented marketing services. Denzin and Lincoln (2011) define qualitative research as a s set of complex interpretive studies, with contradicting between method and interpretation may occur, intersecting all human discipline including physical sciences. By conducting in depth-interview with manager of SIS Bona Vista and Head of Marketing who are in charge on how relationship marketing activities in building customer-oriented marketing services in Singapore Intercultural School Bona Vista. Data Analysis method summarized into three parts: data reduction; data display; and drawing and verifying conclusions. Reliability Test Method is data-triangulation by Todd D. Jick (1979) As explained in journal article 'Mixing Qualitative and Quantitative Methods: Triangulation in Action' mentions that triangulation could provide constructive role and captures problems in-balance to data collection methods, assist researcher disclose dimensions of the phenomenon which is deviant from the theory (Jick, 1979).

\section{RESULT AND DISCUSSION}

$\mathrm{B} 2 \mathrm{C}$ or $\mathrm{B} 2 \mathrm{~B}$ are known in marketers, such $\mathrm{B} 2 \mathrm{~B}$ for Business to Business and $\mathrm{B} 2 \mathrm{C}$ is Business to Consumer (Chauhan \& Anbalagan, 2014). The terms refer to the products and services selling process. B2B is selling process between companies, B2C is selling to end user (Chauhan \& Anbalagan, 2014). Business market in the book of Marketing Management as explained:

"The business market consists of all the organization that acquire goods and services used in the production of other products or services that are sold, rented, or supplied to others. The major industries making up the business market are agriculture, forestry and fisheries; mining; manufacturing; construction; transportation; communication; public utilities; banking, finance and insurance; distribution; and services (Kotler \& Keller, 2014)."

Relationship between SIS Bona Vista and customers considered as B2C given the fact that one is an organization that sell a service. Porter (1985) stated about how firms build competitive strategy for positioning in the industry. Porter explained with various strength and weaknesses one firms pos- 
sess, there are two basic ways to complete with competitors. They are 'cost advantage' and 'differentiation' which could be applied to broad market segmentation (Porter, 1985). Competitive advantage applicable for specific segmentation, which is called 'focus strategy'. Porter (1985) classified focus strategy into 'cost focus' and 'differentiation focus'.

Singapore Intercultural School Bona Vista is an international school that cater elementary to senior high school with three curriculums, which are Singapore, International Baccalaureate and Cambridge by serving various of segmentation which provides competitive advantage in focus strategy. SIS Bona Vista has 'differentiation focus' competitive advantage by implementing best education curriculum, facilities and homey relationship to the customer market of relationship marketing (primary data).

The strategies of Relationship Marketing activities from Singapore Intercultural School Bona Vista that is customer-oriented marketing services has elaborate thoroughly. Being customer-oriented marketing services, it is the Integrated Marketing Communication that is specifically create for the segmentation of Singapore Intercultural School Bona Vista's customer to be able maintain in the process of relationship marketing services. As Singapore Intercultural School Bona Vista's marketing department which specify the department that carry the communication of relationship process, ought, that is been plan in building to maintaining the relationship between SIS Bona Vista to their customers. Thus, this process will lead to the aim of communication which is persuasion as Fristed and Wright stated "the consumers are active and knowledgeable participants in marketers' persuasion efforts and the persuasion knowledge includes motivation, cognitive ability and goals are all factions that will be consider into examining the effectiveness of marketing attempt of persuasion", therefore, the persuasion is gain for the customers to eventually be a part of SIS Bona Vista, therefore, being loyal to SIS Bona Vista and become the brand advocates. It is also to understand that persuasion is active.

Singapore Intercultural Bona Vista is an International School that cater from Elementary to Senior High Schools with International Curriculum. SIS Bona Vista delivers best education systems in the world; Singapore for Preschool and Primary, Cambridge for Secondary, and IB for Junior college.SIS Bona Vista consist of 70\% expatriate students', thus, they implemented pre sales, during and after sales. SIS Bona Vista rely on digital and tradition marketing activities such word of mouth and partnering with embassies SIS Bona Vista learns the needs and characteristics of the customer during pre-sales activities.

Maintaining communication with customer through various of channels by Marketing team ss for Alumni SIS Bona Vista has Alumni group maintained by teachers, thus, to maintain good relations as they are still apart of SIS Family. SIS Bona Vista has Parents Support Group.SIS Bona Vista is family school, where everyone knows each other, SIS Bona Vista deliver the communication and service as stated and presence. Flexibility and openness approach is the key becau- se customers (parents) entrusting SIS Bona Vista with their children and SIS Bona Vista are the second home for the customer's children. Giving the best education quality and in return SIS Bona Vista received good feedback that in result gives them branding and reccommendation.Language barrier as most of SIS Bona Vista's customers are expatriate such Korean, Japanese that does not speak fluent English.

SIS Bona Vista let the customers to let them know their expectation SIS Bona Vista positioned themselves into customer's shoes towards the student's better futureParents Support Group as another channel of SIS Bona Vista to involve parents in Marketing and school activities.SIS Bona Vista's Directors supports the Marketing teamSIS Bona Vista has planned their scope of work and cost approved by Top Management.

SIS Bona Vista Admission and Academic information is the integration of effective communication external approach using Digital such Google Ads, Website, Email, Social Media. Internal communication between teacher and parents through WhatsApp and email, where, Marketing are using WhatsApp, mail chimp, phone line.

SIS Bona Vista Marketing department has sector of focus on relationship marketing activities in building customer-oriented marketing services through pre sales, during and after sales which does not limit to serve the customers (primary data). Thus explained that Singapore Intercultural School Bona Vista's segmentation are 70\% expatriate, whereby, the starting of relationship marketing activities on building the customer-oriented marketing services is through digital media, where, they focus on website, social media such Instagram, Twitter, Facebook along with Google Ads, Search Engine Marketing, Search Engine Optimization, thus, this marketing activities help Marketing department of SIS Bona Vista to reach out to their expatriate target to start communication process that start by an email greeting, by sharing information about the school, useful articles without the urge of sounding forcemeat to join the school - semi soft and hard selling that is implemented by SIS Bona Vista.

Reaching out to communities another added strategy by SIS Bona Vista, they implemented such reaching out to embassies of Korea \& Japan. As an introduction is occur on relationship marketing activities in building the customeroriented marketing services, SIS Bona Vista then will start on during-sales strategy, when the targeted customer visit to Indonesia and has informed SIS Bona Vista to have a school tour, to discuss further more on the information needed, therefore, during sales will be the moment of truth from SIS Bona Vista by giving what they have stated to the targeted customer not only that they are giving the best education systems but also a real quality of school's facilities that correlate to the academic integration of SIS Bona Vista. The system of maintaining an internal communication between marketing and parents are an open and flexible communication, where, Marketing of SIS Bona Vista can be reach throughout WhatsApp, email and Social Media accounts that goes to the relationship between parents and teachers too. An overall information of weekly activities of students is shared through mail chimp called 'SIS Connect'. Another pin 
point, SIS Bona Vista use an application named Academia, whereby, the profile database of students can be access by parents to review and interact.

Determined by the interview on internal informants, there is an obstacle of communication in building the customer-oriented marketing services with customers which is language barrier (primary data). However, SIS Bona Vista provide multi-channel integration, which one of the obstacle in communication they conquer with the help of their marketing in-house program which is the Parents ambassador, as one of their job is to assists the new parents. These parent's ambassador represent their home nationality such Japanese, Korean, Latina American, Indonesian, Indian, Singaporean and Malaysian. These channels include the integration of parents to teachers through WhatsApp, where marketing and parents through email for detailed communication, WhatsApp as daily take in conversation, call for immediate respond and Social Media as to showcase promotion and students work (primary data).

\section{CONCLUSSION}

The study concluded that Singapore Intercultural School Bona Vista has implemented all seven elements in relationship marketing activities in building their customeroriented marketing services. Singapore Intercultural School Bona Vista. Marketing department of SIS Bona Vista works effectively on pre sales, during and after sales service. The Marketing department delivers SIS Bona Vista's vision and mission that equivalent to the quality of SIS Bona Vista by providing best education curriculum, facilities and relationship to the customer-oriented marketing services.

\section{REFERENCES}

Cindyara, A. (2019). Education Minister Makarim seeks support from fellow millennials. Retrieved from Antaranews Website: https://en.antaranews.com/news/135228/education-minister-makarimseeks-support-from-fellow-millennials, (Accedssed on 7 November 2020).

Chauhan, G.M., Anbalagan, C. (2014) Strategy and Trends in B2B Business: Opportunities and Challenges - A Global Perspective. IFSMRC African International Journal of Research in Management, 2(3). Retrieved from http://www.ifsmrc.org/sites/default/files/journal/pdf/6.\%20AIJRM\%2 02305JJ14\%20Mani\%20paper\%20for\%20AIJRM\%20issue\%203.pdf

Christopher, M., Payne, A., \& Ballantyne, D. (1991). Relationship Marketing: Bringing Quality Customer Service and Marketing Together, 7. London: UK, Heinemann.

Denzin, N. K. (1978). The Research Act: A Theoretical Introduction to Sociological Methods. USA: McGrow-Hill.

Denzin, N. K., \& Lincoln, Y., S. (Eds.) (2011). The SAGE Handbook of Qualitative Research, 6. Texas: SAGE.

Fill, C. \& Turnbill, S. (Eds.). (2016). Marketing Communications: discovery, creation and conversations, 331-336. United Kingdom: Pearson Education Limited.
Friested M., \& Wright, P. (1994). The persuasion knowledge model: How people cope with persuasion attempts. Journal of Consumer Research, 21, 1-31.

Gumersson, E. (2011). Total Relationship Marketing, 5-7. UK: Routledge.

Garfinkel, J. (2019). 5 reasons why customer loyalty is important for your business. Widewail. Retrieved from https://www.widewail.com/blog/2019/1/22/5-reasons-why-customerloyalty-is-important-for-your-business, (Accessed on 3 September 2020).

Kotler, P., \& Keller, K. L. (2014). Marketing Management (14 ed), 137. UK: Pearson.

Kotler, P., \& Keller, K. L. (2016). Marketing Management (15 ed), 163. UK: Pearson.

Lawrence, N. W (2014). Social Research Methods: Qualitative and Quantitative Approaches (7 ed), 38-117. UK: Pearson.

Payne. A., \& Frow, P. (2005, October): A Strategic Framework for Customer Relationship Management. Journal of Marketing, 69, 167-176. Doi: ISSN: 0022-2429 (print), 154-7185 (electronic). Retrieved from https://journals.sagepub.com/doi/10.1509/jmkg.2005.69.4.167, (Accessed on 3 September 2020).

Porter, M. (1985). Competitive Advantage: Creating and Sustaining Superior Performance, 11. New York: Free Press.

Punch, K. F (2009). Introduction to Research Methods in Education, 175. New York: SAGE.

Conflict of Interest Statement: The authors declare that the research was conducted in the absence of any commercial or financial relationships that could be construed as a potential conflict of interest.

Copyright $\odot 2021$ Ferguson, et.al.Thisisan open-access article distributed under the terms of the Creative Commons Attribution License (CC BY). The use, distribution or reproduction in other forums is permitted, provided the original author $(s)$ and the copyright owner $(s)$ are credited and that the original publication in this journal is cited, in accordance with accepted academic practice. No use, distribution or reproduction is permitted which does not comply with these terms 